\title{
Reducing copper use in the environment: The use of larixol and larixyl acetate to treat downy mildew caused by Plasmopara viticola in viticulture
}

\section{Short title: Use of larch extracts against Plasmopara viticola}

\author{
Barbara Thuerig $^{\mathrm{a}^{*}}$, Emily E James ${ }^{\mathrm{b}}$, Hans-Jakob Schärer ${ }^{\mathrm{a}}$, Moses K Langat ${ }^{\mathrm{b}}$, Dulcie A \\ Mulholland ${ }^{b}$, Jonas Treutwein ${ }^{c}$, Ina Kleeberg ${ }^{c}$, Mathias Ludwig ${ }^{a}$, Praveen Jayarajah ${ }^{b}$, Oscar \\ Giovannini $^{\mathrm{d}}$, Emilia Markellou ${ }^{\mathrm{e}}$, and Lucius Tamm ${ }^{\mathrm{a}}$
}

\footnotetext{
${ }^{a}$ Research Institute of Organic Agriculture FiBL, Ackerstrasse 113, CH-5070 Frick, Switzerland
}

${ }^{\mathrm{b}}$ Natural Products Research Group, Department of Chemistry, University of Surrey, GU2 7XH, United Kingdom

c Trifolio-M GmbH, Dr.-Hans-Wilhelmi-Weg 1, D-35633 Lahnau, Germany

${ }^{d}$ Fondazione Edmund Mach di San Michele all'Adige FEM, Via E. Mach, 1, I-38010 S.

Michele all'Adige (TN), Italy

e Benaki Phytopathological Institute BPI, 8 Stefanou Delta Street, GR-14561 Kifissia, Athens,

Greece

"Correspondence to: Lucius Tamm, Research Institute of Organic Agriculture, Ackerstrasse 113, CH-5070 Frick, Switzerland. Email: Iucius.tamm@fibl.org

\#Part of this work has been presented in a talk at the 'Deutsche Pflanzenschutztagung' (German congress of plant protection) in D-Halle, 20-23 September 2016

This article has been accepted for publication and undergone full peer review but has not been through the copyediting, typesetting, pagination and proofreading process, which may lead to differences between this version and the Version of Record. Please cite this article as doi: $10.1002 / \mathrm{ps} .4733$ 


\section{Keywords}

Larix decidua, botanical plant protection product, fungicide, Larixyne

\section{Summary}

BACKGROUND: Plant extracts might provide sustainable alternatives to copper fungicides, which are still widely used despite their unfavourable ecotoxicological profile. Larch bark extract and its constituents, larixyl acetate and larixol, have been shown to be effective against grapevine downy mildew (Plasmopara viticola) under semi-controlled conditions. The aim of this study was to reduce the gap between innovation and the registration of a marketable product, namely to develop scalable extraction processes and to evaluate and optimize performance of larch extracts under different conditions.

RESULTS: Toxicologically and technically acceptable solvents like ethanol were used to extract the active compounds larixyl acetate and larixol from bark in sufficient amounts and their combined concentration could be increased up to $39 \%$ by purification steps. The combined concentration of larixyl acetate and larixol from larch turpentine could be increased up to $66 \%$. $\mathrm{MIC}_{100}$ against $P$. viticola in vitro $\left(6-23 \mu \mathrm{g} \mathrm{mL}^{-1}\right)$ and $\mathrm{EC}_{50}$ in planta under semicontrolled conditions $\left(0.2-0.4 \mathrm{mg} \mathrm{mL}^{-1}\right)$ were promising compared to other plant extracts. In vineyards, efficacies of larch extracts reached up to $68 \%$ in a stand-alone strategy and $84 \%$ in low-copper strategies.

CONCLUSIONS: Larch extracts represent valid candidates for copper reduction in organic vineyards, and their development into a sustainable plant protection product might be feasible. 


\section{INTRODUCTION}

Grapevine downy mildew caused by Plasmopara viticola is the most devastating disease of grapevine in humid parts of the world, causing up to $100 \%$ yield losses in susceptible cultivars if left untreated. ${ }^{1}$ Modern copper-based fungicides are used in conventional and integrated as well as in organic wine production. ${ }^{1}$ Even though the use of copper has been drastically reduced thanks to improved formulations and application techniques and the introduction of spray schedules based on decision support systems, ${ }^{1,2}$ the applied amount of copper usually exceeds uptake as a micronutrient by plants, resulting in long-term accumulation in soils, ${ }^{3,4}$ which negatively affects soil organisms and soil fertility. ${ }^{5}$ At the time of writing, there were no substances authorised for European Union organic agriculture which could replace copper fungicides on grapes. ${ }^{6}$ In Switzerland, acidified clay minerals are used with some success, but these are not registered as plant protection products in the European Union. Potassium phosphonate was proposed as a copper alternative in the EU, but was negatively judged by a group of experts (Expert group for technical advice on organic production EGTOP)

(https://ec.europa.eu/agriculture/organic/sites/orgfarming/files/docs/body/egtop-final-reporton-ppp-ii en.pdf ) and its use has not yet been authorised.

The reduction and replacement of copper in organic farming is considered a high priority in European agricultural policy and consequently, the development of copper alternatives which are in accordance with requirements of organic agriculture has been a focus of several EU and national funded research projects in the last two decades, including four projects funded by the EU (BLIGHT-MOP (http://cordis.europa.eu/project/rcn/59048 de.html), REPCO (http://cordis.europa.eu/result/rcn/47894 en.html), ForestSpeCs

(http://cordis.europa.eu/project/rcn/91266 en.html), Co-FREE (http://www.co-free.eu/)), Within the project REPCO, we screened 112 products deemed compatible with organic agriculture for their efficacy against $P$. viticola under greenhouse and field conditions. ${ }^{7}$ Products ranged from experimental, semi-developed to registered and commercially 
available products. Materials tested included biocontrol organisms, putative inducers of resistance and fungicides and were of mineral, animal or plant origin. In this study, only four products, acidified clay, a biocontrol organism (Trichoderma harzianum) and two plant extracts (Yucca schidigera, Salvia officinalis) showed promising results under field conditions. $^{7}$

Other studies have identified other plant extracts with promising activity against $P$. viticola, including extracts of Glycyrrhiza glabra, ${ }^{8}$ Inula viscosa, ${ }^{9}$ Vitis vinifera canes ${ }^{10}$ and Juncus effusus, ${ }^{11}$ and Puopulo et al. described a high efficacy of cells and culture filtrate of the bacterium Lysobacter capsici. ${ }^{12,13}$ In the research project, ForestSpeCs, we succeeded in identifying five tree species, Larix decidua Mill., Larix gmelinii (Rupr.) Kuzen., Larix sibirica Ledeb., Pinus sylvestris L. and Picea abies containing constituents with good to excellent efficacy against $P$. viticola under greenhouse conditions. ${ }^{14}$ In bark extracts we identified a range of active compounds, including larixol, larixyl acetate, lariciresinol and lariciresinol acetate from Larix species and $7 \alpha, 15$-dihydroxydehydroabietic acid from Pinus sylvestris. ${ }^{14}$ Bark is a by-product of the forestry industry and is highly suitable as a raw material to produce botanical plant protection products, since (i) it is available in large and constant amounts at relatively low prices, (ii) a favourable environmental profile with respect to environmental impact and use of renewable resources can be expected, and (iii) it has a high potential to provide an opportunity to the forest industry to transform low value by-products into high value-added products (Mantau U (http://www.cepi.org/wood_flows_in_Europe). ${ }^{15}$ Yet, bringing potential plant protection products to the market necessitates substantial investments, not only in development of the product itself but also in the preparation of a registration dossier. ${ }^{16}$ Therefore, the overall aim of the follow-up project (FP7-KBBE ProLarix,http://www.prolarix.eu/homepage.html) was to reduce the gap between innovation and the registration of a marketable product. Larix decidua, the species producing the most efficacious plant extract in our previous project, and its active ingredients, larixyl acetate and larixol, were selected for further studies. Larix decidua is a long-living, fast-growing pioneer coniferous tree naturally occurring in the central and eastern Alps, producing a durable wood 
used for carpentry, furniture and pulp for the paper industry. ${ }^{17}$ It is an important silvicultural species in the European alpine regions but is also cultivated outside its natural range such as the non-alpine regions of Germany, Austria, and France, the Czech Republic, Slovakia, Great Britain, Scandinavian countries, Poland, Hungary, and even in Canada, north-eastern United States and New Zealand. ${ }^{17}$

This study aimed to (i) develop scalable extraction processes of a standardised larch extract, and (ii) to optimize its performance and to develop application strategies for a range of pedoclimatic conditions.

\section{MATERIAL AND METHODS}

\subsection{Plant material}

\subsubsection{Stem bark of Larix decidua}

The stem bark of Larix decidua Mill. was collected in December 2013 from Bergün in Switzerland (N 46.3748, E 9.450) at $1370 \mathrm{~m}$ a.s.I.. The plant was identified at the Research Institute of Organic Agriculture ( $\mathrm{CH}-$ Frick) and a voucher specimen was retained. The stem bark was air-dried and ground using a Glen-Creston cross beater mill. Two sizes of ground stem bark were prepared using 4 and $10 \mathrm{~mm}$ sieves.

\subsubsection{Larch turpentine from $\mathrm{L}$. decidua}

Larch turpentine, an oleoresin produced from L. decidua, was sourced from C.E. Roeper GmbH, D-Hamburg (Type 109.327) who obtained it from Austrian larch.

\subsection{Development of a method for extracting the active compounds from the stem bark of L. decidua}

\subsubsection{General procedures}

All extracts were analysed for larixyl acetate, larixol and epimanool (Fig. 1) content using GC-MS and GC-FID methods (see section 2.4.2.3). Epimanool, a compound with a structure similar to larixyl acetate and larixol (Fig. 1) present in significant amounts in extracts (data not shown) and in larch turpentine (21\%, Tab. 5), did not show any activity against $P$. viticola 
in concentrations corresponding to its content in the extract (Fig. 2), and thus contents of epimanool are not displayed in tables.

\subsubsection{Soxhlet extraction of stem bark}

2.2.2.1 Soxhlet extractions of stem bark using dichloromethane, ethyl acetate and methanol separately

Separate Soxhlet extractions of milled (4 mm particle size) L. decidua stem bark (100 g) were performed for two hours each using either dichloromethane $\left(\mathrm{CH}_{2} \mathrm{Cl}_{2}\right)$, ethyl acetate (EtOAc) or methanol $(\mathrm{MeOH})(500 \mathrm{~mL})$. The extracts were allowed to stand, then were decanted and filtered. The filtrates were concentrated under reduced pressure to obtain crude extracts which were analysed. Extract yields and composition of the extracts are presented in Tab. 1.

2.2.2.2 Successive Soxhlet extraction of the stem bark using dichloromethane followed by methanol

Soxhlet extraction of milled (4 mm particle size) L. decidua stem bark (100 g) was performed for two hours with $\mathrm{CH}_{2} \mathrm{Cl}_{2}(500 \mathrm{~mL})$, the solvent was removed and the sample was extracted for a further two hours with $\mathrm{MeOH}(500 \mathrm{~mL})$. The extracts were allowed to stand, then decanted and filtered. The filtrates were concentrated under reduced pressure to obtain crude extracts which were analysed. Extract yields and composition of the extracts are presented in Tab. 1.

\subsubsection{Large scale extraction of the stem bark of $L$. decidua using methanol}

An extract from the bark of $L$. decidua to be tested in field trials 2014 in $\mathrm{CH}$-Frick was prepared using two sets of Soxhlet apparatus with capacity to hold $800 \mathrm{~g}$ and $500 \mathrm{~g}$ of powdered stem bark, and $8 \mathrm{~L}$ and $4 \mathrm{~L}$ of $\mathrm{MeOH}$ respectively, for 16 hours per extraction. $\mathrm{A}$ total of $18.5 \mathrm{~kg}$ of stem bark was extracted over a $35 \mathrm{~d}$ period. Extracts were allowed to stand to reach room temperature, then decanted and filtered. The filtrate was concentrated 
under reduced pressure to obtain a combined crude extract $(1.3 \mathrm{~kg})$ which was analysed. Extract yields and composition of the extracts are presented in Tab. 1.

\subsubsection{Extraction of stem bark by agitation}

A range of solvents thought to be feasible for large-scale extraction (economically feasible; respecting safety regulations regarding explosion hazard, flammability, toxicity, environmental impact, and residues) were investigated. Solvents tested were acetone, petroleum ether, ethanol, water, and ethanol-water mixtures (1:1). Powdered $4 \mathrm{~mm}$ or $10 \mathrm{~mm}$ particle size stem bark of $L$. decidua $(100 \mathrm{~g})$ was transferred to a conical flask $(1 \mathrm{~L})$ and solvent $(500 \mathrm{~mL})$ was added. The conical flasks were left on an automated shaker at room temperature $(\mathrm{RT})$ or on a heated water bath (set at $100^{\circ} \mathrm{C}$ ) for 8 hours. The extracts were allowed to stand, decanted and filtered. The filtrates were concentrated under reduced pressure to obtain crude extracts which were analysed. Yields and chemical compositions are presented in Tab. 2.

\subsubsection{Removal of sugars from selected stem bark extracts}

Selected extracts (1 $\mathrm{g}$ of each) obtained as described in section 2.2.2 were dissolved in 100 $\mathrm{mL}$ petroleum ether (Fisher Scientific, $40-60^{\circ} \mathrm{C}$ fraction) at room temperature in conical flasks. The conical flasks were left on an automated shaker to extract for 2 hours. The extracts were allowed to stand, decanted and filtered. The filtrates were concentrated under reduced pressure to obtain oily extracts which were analysed. Yields and chemical composition of the extracts are presented in Tab. 3.

\subsubsection{Removal of diterpene acids from selected stem bark extracts}

The cold ethanol:water (1:1) extracts ( $4 \mathrm{~mm}$ and $10 \mathrm{~mm}$ particle size) ( $1 \mathrm{~g}$ of each) obtained as described in section 2.2.2 were re-dissolved in petroleum ether $(100 \mathrm{~mL})$ (Fisher Scientific, $40-60^{\circ} \mathrm{C}$ fraction) and transferred to a three-neck round bottom flask (500 $\left.\mathrm{mL}\right)$ fitted with a condenser, dropping funnel and a thermometer. 2-Amino-2-methyl-1-propanol (AMP) (2 mL) (Sigma Aldrich, 95\%, $\mathrm{H}_{2} \mathrm{O} 5 \%$ ) was placed in a dropping funnel. The solution 
was refluxed at $60{ }^{\circ} \mathrm{C}$ for $30 \mathrm{~min}$ to allow for complete dissolution and the amine was added drop wise over 30 minutes. The mixture was refluxed for $1 \mathrm{~h}$, then cooled to room temperature by standing for approximately 2 hours. The precipitate was removed using gravity filtration through cotton wool. The precipitate was washed three times with petroleum ether (50 $\mathrm{mL} \times 3)$ to recover any entrapped diterpenoid alcohols. The filtrate was concentrated under reduced pressure to yield an oily product which was analysed. Yields and chemical composition are presented in Tab. 4.

\subsection{Extraction of larixol and larixyl acetate from larch turpentine}

Diterpene acids were removed from larch turpentine by gently heating larch turpentine $(1 \mathrm{~kg})$ with $n$-hexane $(2.5 \mathrm{~L})$ (Sigma Aldrich) to reflux (approx. $70^{\circ} \mathrm{C}$ ) in a $5 \mathrm{~L}$ round-bottomed flask containing anti-bumping granules and equipped with a refluxing condenser. Heating with regular swirling was continued until the turpentine dissolved. AMP $(150 \mathrm{~mL})$ was added slowly to the refluxing solution while swirled to form a resin acid - amine salt precipitate. As the reaction between the resin acid and the amine is exothermic, the amine was added slowly. The undesired resin acid - amine salt precipitated immediately as a thick white solid. The batch was cooled to room temperature and the resin acid - amine salt was filtered off using vacuum or press filtration and the filtrate was recovered. The precipitate was washed three times with hexane to remove any entrapped diterpenoid alcohols. The filtrates were combined, solvent was removed by distillation and the extracts were analysed. Distillation also allowed for other volatiles (mainly monoterpenes and hydrocarbons) to be removed. ${ }^{1} \mathrm{H}$ NMR analysis was undertaken to confirm that all resin acids had been removed. A yield of $420 \mathrm{~g}$ of extract per $\mathrm{kg}$ of larch turpentine could be produced using this method. The resulting oily product was analysed for larixyl acetate, larixol and epimanool content using GC-MS and GC-FID methods. It contained mainly larixyl acetate, larixol and epimanool and minor amounts of other labdane, abietane and isopimarane alcohols.

This method was used to produce approximately $2.0 \mathrm{~kg} \mathrm{(2014)} \mathrm{and} 6.0 \mathrm{~kg}(2015)$ of a larch turpentine extract that was used in field experiments in 2014 and 2015 (Tab. 5).

This article is protected by copyright. All rights reserved. 


\subsection{Analytical methods}

\subsubsection{Isolation of analytical standards}

Larixyl acetate, larixol and epimanool standards were isolated from larch turpentine using a Grace Reveleris ${ }$ X2 Flash Chromatography System. The compounds were separated using gradient elution (hexane: $\mathrm{CH}_{2} \mathrm{Cl}_{2}$ 100:0 to 0:100 over 27 minutes, $100 \% \mathrm{CH}_{2} \mathrm{Cl}_{2}$ for 10 min, then $\mathrm{CH}_{2} \mathrm{Cl}_{2}$ :EtOAc 100:0 to $80: 20$ for $35 \mathrm{~min}$ ). The fractions were purified using gravity column chromatography over silica gel (Merck Art. 9385) using $\mathrm{CH}_{2} \mathrm{Cl}_{2}$ as the mobile phase. The purity of the isolated standard compounds was determined as $>95 \%$ using HPLC.

\subsubsection{Characterization of larixol, larixyl acetate and epimanool}

\subsubsection{GC-MS analysis of analytical standards}

GC-MS analysis was performed on an Agilent Technologies 7890A GC-system equipped with a Zebron ZB5MS, $30 \mathrm{~m} \times 0.25$ (i.d.) mm, column and Agilent Technologies 5975C inert $\mathrm{XL} \mathrm{El/CI} \mathrm{MSD} \mathrm{with} \mathrm{triple} \mathrm{axis} \mathrm{detector.} \mathrm{Helium} \mathrm{was} \mathrm{used} \mathrm{as} \mathrm{the} \mathrm{carrier} \mathrm{gas}\left(1 \mathrm{~mL} \mathrm{~min}^{-1}\right)$, with an injection volume of $2 \mu \mathrm{L}$ and inlet temperature of $280^{\circ} \mathrm{C}$. The oven temperature was programmed as follows: $50^{\circ} \mathrm{C}$ held for $3 \mathrm{~min}, 50$ to $250^{\circ} \mathrm{C}$ at $10^{\circ} \mathrm{C} \mathrm{min}{ }^{-1}$ and held at $250^{\circ} \mathrm{C}$ for $12 \mathrm{~min}$ to give a total run time of $35 \mathrm{~min}$ ). The retention time for larixyl acetate was 23.90 $\mathrm{min}$, for larixol $23.07 \mathrm{~min}$ and for epimanool $21.13 \mathrm{~min}$. Chromatograms and mass spectra are provided in Supplementary Information S1.

\subsubsection{NMR analysis}

${ }^{1} \mathrm{H},{ }^{13} \mathrm{C}$ and 2D NMR spectra were recorded in $\mathrm{CDCl}_{3}$ on a Bruker AVANCE III NMR spectrometer, operating at $500 \mathrm{MHz}$ for ${ }^{1} \mathrm{H}$ and $125 \mathrm{MHz}$ for ${ }^{13} \mathrm{C}$ spectra, using standard experiments from the Bruker Pulse Programs Library. NMR data and spectra are provided in Supplementary Information S1.

\subsubsection{Analysis of extracts}


Extracts were analyzed quantitatively in triplicate using capillary gas chromatography with a flame ionization detector (GC-FID) on an Agilent Technologies 6890N GC instrument (Agilent Technologies, Santa Clara, California) equipped with a Rt $®-\gamma D E X s a$ (fused silica), $30 \mathrm{~m} \times$ 0.32 (i.d.) mm, $0.25 \mu \mathrm{m}$ (film thickness) (Restek, Bellefonte, Pennsylvania) capillary column. The injector and detector temperatures were maintained at 250 and $260^{\circ} \mathrm{C}$ respectively with an injection volume of $4 \mu \mathrm{l}$, with a split ratio of 1:25. Hydrogen was used as carrier gas $(1 \mathrm{~mL}$ $\left.\mathrm{min}^{-1}\right)$ and detector gas $\left(15 \mathrm{~mL} \mathrm{~min}{ }^{-1}\right)$ with air $\left(280 \mathrm{~mL} \mathrm{~min}^{-1}\right)$. Nitrogen was used as makeup gas $\left(15 \mathrm{~mL} \mathrm{~min}{ }^{-1}\right)$. The oven temperature was programmed from 200 to $350^{\circ} \mathrm{C}$ as follows: $200^{\circ} \mathrm{C}$ held for 3 minutes, 200 to $300^{\circ} \mathrm{C}$ at $20^{\circ} \mathrm{C} \mathrm{min}-1$, held at $300^{\circ} \mathrm{C}$ for $4 \mathrm{~min}, 300$ to $350^{\circ} \mathrm{C}$ at $25^{\circ} \mathrm{C} \mathrm{min}-1$ and held at $350^{\circ} \mathrm{C}$ for $1 \mathrm{~min}$. A 5 minute post run at $50^{\circ} \mathrm{C}$ gave a total run time of $20 \mathrm{~min}$.

A standard solution of the three major diterpenoids present in the extracts was prepared by dissolving $0.1 \mathrm{~g}$ of each of the purified larixyl acetate, larixol and epimanool in $\mathrm{MeOH}(100$ $\mathrm{mL}$ ). This solution was used to prepare external calibration standards. Ten-point calibration curves $(20-1000 \mu \mathrm{g})$ were used to quantify the active compounds in samples and were constructed from calibration standards analyzed at the start or end of each set of samples. The retention time for larixyl acetate was $11.61 \mathrm{~min}$, for larixol $10.80 \mathrm{~min}$ and for epimanool $9.20 \min$.

\subsection{Formulation of extracts for plant-pathogen bioassays and field experiments}

To improve handling (e.g. solubility) and agronomical properties (e.g. rain fastness), larch turpentine extract (section 2.3, Tab. 5) and larch stem bark extract (section 2.2.1.3, Tab. 1) were formulated for controlled-condition bioassays and field experiments. Formulations differing in the content of the plant extract and the type of solvents, emulsifiers, and adjuvants, were developed in an iterative process optimising physico-chemical as well as agronomic properties of formulations. All selected formulations were emulsifiable concentrates (EC), emulsifying spontaneously when added to water producing a spraying solution. LAR-016 was composed of $25 \%$ larch turpentine extract, $5 \%$ emulsifier(s), $5 \%$ adjuvant(s) and $65 \%$ of 
solvent(s). LAR-042 contained 50\% larch turpentine extract, $5 \%$ emulsifier(s), $5 \%$ adjuvant(s) and $40 \%$ solvent(s). The selected formulation based on larch stem bark extract (LAR-024) contained $20 \%$ larch bark extract, $10 \%$ emulsifier(s), $20 \%$ adjuvant(s) and $50 \%$ solvent(s). The adjuvants were slightly modified after the first three treatments (6 to 26 May 2014) to improve rain fastness.

\subsection{In vitro bioassays}

The concentrations needed to completely inhibit germination and/or activity of zoospores $\left(\mathrm{MIC}_{100}\right)$ of Plasmopara viticola (Berk. \& M.A. Curtis) Berl. \& De Toni were assessed in vitro in 96-well plates. Larixyl acetate and larixol were dissolved in $99.8 \% \mathrm{EtOH}$ at $10 \mathrm{mg} \mathrm{mL}^{-1}$. Formulated larch turpentine extracts (LAR-016, LAR-042), larixyl acetate and larixol were serially diluted $1: 1$ in water down to $20 \mu \mathrm{gL}^{-1}$ (10 concentrations). As controls, serial dilutions of the blank formulations LAR-016 and LAR-042 and of EtOH were included. Each test product $(6 \mu \mathrm{L})$ was added to $94 \mu \mathrm{L}$ of a mineral water $\left(\right.$ Evian ${ }^{\circledR}$, favourable for activity of zoospore of $P$. viticola). Sporangia suspensions of $P$. viticola were prepared by washing fresh, sporulating grapevine leaves and filtering suspensions over a cheese cloth.

Concentration of the sporangia suspension was adjusted to $1.8-2.5 \times 10^{5}$ sporangia $\mathrm{mL}^{-1}$ before adding $20 \mu \mathrm{L}$ to each well of the test plate. Resulting test concentrations were between 1 and $500 \mu \mathrm{g} \mathrm{mL}^{-1}$.

Effects of extracts were assessed 2-3 h after set-up of the experiment. All assessments were made using a binocular at magnifications of x 50 - 100. Three inhibition levels were scored: 0 (similar to water control), 1 (distinct reduction in number and/or activity of zoospores), and 2 (no zoospores germinated or all zoospores inactive).

\subsection{Plant-pathogen bioassays under semi-controlled conditions}

For plant-pathogen bioassays under semi-controlled conditions, small grapevine ( $\mathrm{cV}$. 'Chasselas') plants grown from seeds were transplanted to individual pots $(0.275 \mathrm{~L})$ 
containing a standard substrate ('Einheitserde Typ 0', Gebr. Patzer GmbH \& Co. KG, DSinntal-Jossa) previously amended with a mineral fertilizer $\left(3 \mathrm{~g} \mathrm{~L}^{-1}\right)($ Tardit $3 \mathrm{M}$, Hauert Günther Düngerwerke $\mathrm{GmbH}, \mathrm{D}$-Erlangen). Plants were grown in the greenhouse at a temperature of 18 to $32^{\circ} \mathrm{C}$ under natural light. The photoperiod was extended with mercury lamps if necessary to allow for a light period of $16 \mathrm{~h}$ throughout the whole year. Plants were used for bioassays when they had 3-4 fully developed leaves (2-3 weeks after transplanting). Plasmopara viticola was maintained on grapevine (Vitis vinifera L.) seedlings cv. 'Chasselas' by weekly re-inoculation (described below). Sporangia suspensions of $P$. viticola were gained as described above (section 2.6) and adjusted to $5 \times 10^{4}$ sporangia $\mathrm{mL}^{-1}$ (a concentration reproducibly causing severe disease symptoms in non-treated control plants under selected conditions).

Formulated larch turpentine extracts were dissolved in demineralised water, pure compounds were dissolved in $\mathrm{EtOH}$ at concentrations of $10 \mathrm{mg} \mathrm{mL}^{-1}$ before diluting into demineralised water. For dose-response curves, products were serially diluted 1:1. Extracts were tested in concentrations between 0.0075 and $1 \mathrm{mg} \mathrm{mL}^{-1}$, pure compounds in concentrations between 0.03 and $1 \mathrm{mg} \mathrm{mL}^{-1}$. A non-treated non-inoculated control, a non-treated inoculated control and a standard treatment (copper hydroxide, Kocide ${ }^{\circledR}$ Opti ${ }^{\mathrm{TM}}$, DuPont de Nemours, Wilmington, DE, USA) at two concentrations $\left(300 \mu \mathrm{g} \mathrm{mL}^{-1}\right.$ and $30 \mu \mathrm{g} \mathrm{mL}^{-1}$ of $\left.\mathrm{Cu}^{2+}\right)$ were included in each experimental set. Each treatment was tested on six replicate plants. Plants were sprayed with the test products using an automatic spray cabinet (extracts) or an airassisted hand sprayer (DeVilbiss ${ }^{\circledR}$ Compact MINI HVLP Touch-Up Spray Gun) (pure compounds) until leaves (adaxial and abaxial side) were completely covered with a dense layer of small droplets. Plants were subsequently left to dry at room temperature before inoculation with $P$. viticola using an air-assisted hand sprayer on the the abaxial leaf side. Inoculated plants were incubated at $20-21^{\circ} \mathrm{C}$ and $80-99 \%$ of relative humidity $(\mathrm{RH})$ in the light for $24 \mathrm{~h}$. Then, plants were maintained at $20^{\circ} \mathrm{C}, 60-80 \% \mathrm{RH}$, and a $16 / 8-\mathrm{h}$ day/night light regime. 5 to $6 \mathrm{~d}$ after inoculation, plants were incubated over night in the dark at $20^{\circ} \mathrm{C}$ and $80-99 \%$ to promote sporulation. Disease incidence (percentage of leaves with disease 
symptoms) and disease severity (percentage of leaf area covered by lesions) were assessed 6 to $7 \mathrm{~d}$ after inoculation. All disease assessments were made using continuous values of percentage based on the European and Mediterranean Plant Protection Organisation (EPPO) standard scale. ${ }^{18}$

\subsection{Field trials}

\subsubsection{Vineyards}

$\mathrm{CH}-$ Frick is an experimental vineyard situated in the North-Western part of Switzerland (Frick, $\mathrm{N} 47.314^{\circ}, \mathrm{E} 08.0133^{\circ}, 385 \mathrm{~m}$ a.s.I.) on a clay loam. Average annual rainfall is 1138 mm (mean 2005-2014, www.agrometeo.ch). It was established in 1997 and consists of 576 plants of the susceptible grapevine varieties 'Müller-Thurgau' ('Riesling x Sylvaner') and 'Chasselas' ('Gutedel') (288 plants per variety) grafted on rootstock 5BB. A gobelet training system was used, with plant distances of $2 \mathrm{~m}$ between rows, and $1.1 \mathrm{~m}$ within rows. The vineyard is maintained in line with organic regulation and according to regional best farming practice. Weather data were recorded throughout the season with a Campbell weather station close to the vineyard (www.agrometeo.ch).

I-San Michele: The experimental vineyard is situated in northern Italy (San Michele a/A; N 46.1845, E 11.1244; $228 \mathrm{~m}$ a.s.I.) on a calcareous loam and was planted in 2003. The cultivar is Pinot gris SMA 514 grafted on SO4 rootstock. The training system is double pergola trentina ( 5.5 by $0.66 \mathrm{~m}$ ). The vineyard is maintained in line with Integrated Pest Management practices and according to regional best farming practice.

GR-Veria: The experimental vineyard is situated in the Municipality of Veria, prefecture of Imathia in Northern Greece (N 40.635531, E 22.198726, $27 \mathrm{~m}$ a.s.I.) and was planted in 1997 in a Trellis training system. The cultivar is Chardonnay grafted on 110 Richter. The distance within rows was $1.3 \mathrm{~m}$, the distance between rows was $2.5 \mathrm{~m}$. These data were used in addition to height in order to calculate the Leaf Wall Area in order to adjust the spraying volumes (procedure for this training system only). The vineyard is maintained in line 
with Integrated Pest Management Certification and according to regional best farming practice.

\subsubsection{General procedures}

Efficacies of standardised larch extracts (Larixyne ${ }^{\circledR}$ ) against grapevine downy mildew (Plasmopara viticola) were tested under field conditions (natural infection, no artificial inoculation). The experiments were conducted following EPPO guidelines (PP 031/1 Plasmopara viticola; PP 152/4 Design and Analyses of Efficacy Trials; PP 181/4 Conduct and Reporting of Efficacy Trials-GEP; PP 135/3 Phytotoxicity assessment ; PP 1/225(3) Minimum effective dose)(http://pp1.eppo.int/).

\subsubsection{Experimental designs}

All field trials were arranged in a randomized complete block design with four blocks, each treatment replicate consisting of 6 plants per variety (totalling 12 plants)(CH-Frick), 8-9 plants (I-San Michele) or 7 plants (GR-Veria), respectively. In $\mathrm{CH}$-Frick, due to the age of the vineyard and its previous use in trials, there were some plants of low quality, resulting in some replicates consisting of less than 12 plants.

\subsubsection{References and products}

\subsubsection{Control and reference treatments}

All field trials included a non-treated control as a reference for natural development of disease epidemics and a copper control containing $\mathrm{Cu}^{2+}$ in the form of $\mathrm{Cu}(\mathrm{OH})_{2}$. In $\mathrm{CH}$-Frick, Kocide ${ }^{\circledR}$ Opti $^{\mathrm{TM}}$ (DuPont de Nemours, Wilmington, DE, USA) containing $30 \% \mathrm{Cu}^{2+}$ was used at a concentration of $0.5 \mathrm{~g} \mathrm{Cu}^{2+} \mathrm{L}^{-1}$. In I-San Michele, Coprantol Hi Bio (Syngenta AG, $\mathrm{CH}-$ Basel) containing $25 \% \mathrm{Cu}^{2+}$ was used at concentrations of $0.45-0.9 \mathrm{~g} \mathrm{Cu}^{2+} \mathrm{L}^{-1}$. In GR-Veria, Kocide ${ }^{2} 2000$ (DuPont de Nemours, Wilmington, DE, USA) containing $35 \% \mathrm{Cu}^{2+}$ was used at a concentration of $0.7 \mathrm{~g} \mathrm{Cu}^{2+} \mathrm{L}^{-1}$. Resulting amounts of $\mathrm{Cu}^{2+}$ applied per ha and year were 4.5 (CH-Frick 2014), 4.8 (CH-Frick 2015), 7 (I-San Michele) and 7.7 (GR-Veria) kg ha-1 $\mathrm{y}^{-1} . \mathrm{CH}-$ Frick included a second reference strategy ('Strategy Praxis'), the plant protection strategy recommended by the FiBL-advisory service to Swiss organic grapevine producers. ${ }^{19,20}$ The 
spray schedule started with the use of $0.8 \%$ Myco-Sin ${ }^{\circledR}$ (Andermatt Biocontrol, $\mathrm{CH}$ Grossdietwil) (65\% acidified clay minerals, $0.2 \%$ horsetail extract) plus $0.5 \%$ Sulfur Stulln (80\% sulphur; Andermatt Biocontrol) in tank mixture. Around bloom, depending on infection pressure and rainfall, there was a change to Kocide ${ }^{\circledR} \mathrm{Opti}^{\mathrm{TM}}(0.1 \%)$, which was sprayed until the end of the season. The change to copper was on 5 July 2014 and on 22 June 2015, after 8 or 6 copper-free treatments, respectively, resulting in $2.4(2014)$ or $3(2015) \mathrm{kg} \mathrm{Cu}^{2+} \mathrm{ha}^{-1} \mathrm{y}^{-}$ 1.

I-San Michele included a treatment ('Control-Cu-Control') receiving a standard copper treatment during bloom, but remaining untreated before and after bloom.

\subsubsection{Test products}

The formulation LAR-016 based on larch turpentine extract (section 2.3) was tested in 2014 in $\mathrm{CH}-$ Frick, and in 2015 in CH-Frick, I-San Michele and GR-Veria. In 2014, a concentration with an efficacy $>95 \%$ under semi-controlled conditions $\left(1 \mathrm{~g}\right.$ extract $\left.\mathrm{L}^{-1}\right)(\mathrm{Fig} .3$ was selected for field tests. In 2015 , test concentration was increased to $2 \mathrm{~g}$ extract $\mathrm{L}^{-1}$ to avoid a putative underperformance due to sub-optimal concentrations. LAR-042 based on the same larch turpentine extract as LAR-016 was tested at a concentration of $2 \mathrm{~g}$ extract $\mathrm{L}^{-1}$ in 2015 in $\mathrm{CH}$ Frick (2015).

The formulation LAR-024 based on larch bark extract (section 2.2.1.3) was tested in 2014 in $\mathrm{CH}-F$ rick. The concentration of LAR-024 was gradually increased during the season from $1 \mathrm{~g}$

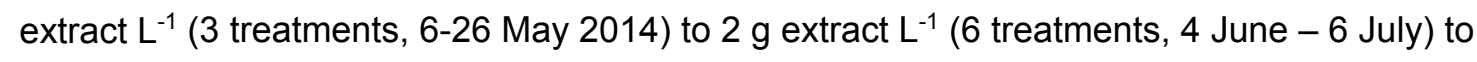
$5 \mathrm{~g}$ extract $\mathrm{L}^{-1}$ (10 treatments, 1 July -20 August).

\subsubsection{Products against powdery mildew caused by Erysiphe necator}

To control powdery mildew, systemic products having no effect against grapevine downy mildew were used in I-San Michele and GR-Veria. All products were used at recommended dosages. In I-San Michele, Arius ${ }^{\mathrm{TM}}$ (Dow AgroSciences, I-Bologna) containing 22.58\% quinoxyfen was used at 25-30 mL hL-1 , Prosper 300CS (Bayer, I-Milano) containing $30.28 \%$ spiroxamine was used at 0.7-1.3 $\mathrm{L} \mathrm{ha}^{-1}$, Support $10 \mathrm{EC}$ (Agrimag, I-Corato) containing 10.2\% 
penconazole was used at 25-50 $\mathrm{mL} \mathrm{hL}^{-1}$, and Vivando® (Bayer, I-Milano) containing $50 \%$ metrafenone was used at 0.08-0.32 L ha-1. In GR-Veria, Kumulus ${ }^{\circledR} S 80$ WG (BASF, DLudwigshafen) containing $80 \%$ wettable sulfur was used at $2.4-4.8 \mathrm{~kg} \mathrm{ha}^{-1}$, and Topas ${ }^{\circledR} 100$ EC (Syngenta, $\mathrm{CH}$-Basel) containing $10 \%$ penconazole was used at $12.5 \mathrm{~mL} \mathrm{hL}^{-1}$. In $\mathrm{CH}-$ Frick, no fungicides against $E$. necator were applied, resulting in natural powdery mildew infections in some years.

\subsubsection{Application}

\subsubsection{Application technique}

$\mathrm{CH}-$ Frick: Products were applied using pressure based and pressure tank supported spray systems (spray gun: GTi Pro light pressure, DeVillbiss, USA; pressure tank: pressure feed cup KB-522-SS, DeVillbiss, USA; 4 bar spray pressure) using a spray volume of $400-600 \mathrm{~L}$ ha ${ }^{-1}$. Plants were treated by spraying the product from above and from below, which resulted in a homogeneous coating of the abaxial and adaxial leaf surface. Spray distribution was verified using water-sensitive paper (Novartis). I-San Michele: Products were sprayed with a motorized backpack mistblower (Solo $450 \circledast$, Germany) using a spray volume of $550 \mathrm{~L} \mathrm{ha}^{-1}$. GR-Veria: Products were applied using a backback sprayer (Oleo-Mac, Bagnolo in Piano, Italy) at a pressure of 15.2 bar with $800 \mathrm{~L} \mathrm{ha}^{-1}$.

\subsubsection{Application strategy}

$\mathrm{CH}$-Frick: Plants were treated according to weather conditions and risk for infection, calculated by the decision support system 'vitimeteo' (www.agrometeo.ch). Decision Support Systems use information on the pathogen, observed weather and weather forecast to identify periods with high risk of infection. ${ }^{21}$ Treatments started on 6 May in 2014 or on 13 May in 2015 and ended on 20 August in 2014 or on 21 August in 2015. In both years, a total of 16 applications were performed in intervals ranging from 3 to $10 \mathrm{~d}$.

I-San Michele: The probable infection periods of Plasmopara viticola were identified based on "Meteo 3B" weather forecast. Plants were treated before rainfall and re-treated after wash-off (25-30 mm). The effectiveness of LAR-016 was evaluated in a combined strategy in 
which copper was applied during bloom (four treatments between 21 May and 5 June), when plants are highly susceptible to grapevine downy mildew, whereas LAR-016 was applied before and after bloom.

GR-Veria: Plants were treated according to weather conditions and risk for infection, calculated by the decision support system 'FieldClimate.com' (https://www.fieldclimate.com/). Treatments started on 7 May 2015 and ended on 7 August 2015. A total of 11 applications in intervals of 5 to $14 \mathrm{~d}$ were performed. To reduce overall disease pressure, the $3^{\text {rd }}$ application (23 May 2015) was performed with copper (standard concentration) instead of LAR-016.

\subsubsection{Disease assessment}

\subsubsection{Plasmopara viticola}

All disease assessments were in full accordance with EPPO guidelines. $\mathrm{CH}-F$ rick: Grapevine downy mildew was assessed three (5, 19 and 27 August 2014) or four (26 June, 3 July, 23 July, 18 August 2015) times by scoring disease incidence (proportion of leaves with symptoms) and disease severity (proportion of diseased leaf area) of $P$. viticola (grapevine downy mildew) on leaves (assessment of 100 or (if there were less leaves) all leaves per plant on all individual plants). Percentage grape area infected by $P$. viticola was assessed on 24 July 2015 (assessment of all grapes per plant, all plants per variety and replication). In 2014 , late occurrence of grapevine downy mildew after powdery mildew infections did not allow for a grapevine downy mildew disease assessment on grapes. Instead, overall damage on grapes caused by downy and powdery mildew was assessed on 9 September 2014 for each treatment replicate.

I-San Michele: Disease was assessed eight times between 6 May and 29 July 2015 in intervals of 7-12 d. For each treatment replicate, 60 leaves and 40 bunches were evaluated on the four central plants in each plot. 
GR-Veria: Disease was assessed seven times between 2 July and 14 August 2015 in intervals of $7 \mathrm{~d}$. The percentage leaf area infected per plant (samples of 100 leaves) and the percentage infected leaves per plant (samples of 100 leaves) was assessed.

\subsubsection{Erysiphe necator (powdery mildew)}

Powdery mildew on leaves was assessed in CH-Frick once per season (11 August 2014, 24 July 2015). In 2014, the percentage leaves with infections and the infected leaf area was assessed for all plants on 50 leaves per plant. In 2015, plants were categorized into four classes ( 0 : no symptoms; 1 : low disease level ( $<10 \%$ of leaves show $1-2$ colonies); 2 : intermediate disease level (> $10 \%$ of leaves show symptoms/ more than 2 colonies on leaves); 3: high disease level (predominantly old necrotic spots / symptoms through all leaf ages) (assessment of all leaves per plant, all plants per variety and replication).

\subsection{Calculations and Statistics}

To calculate mean and confidence intervals of $\mathrm{MIC}_{100}$ values, data were $\log _{2}$-transformed. $95 \%$ confidence intervals were calculated from transformed data as $A \pm 1.96 \times B \times n^{-0.5}$, with $\mathrm{A}=$ mean $\mathrm{MIC}_{100}, \mathrm{~B}=$ standard deviation $\mathrm{MIC}_{100}$ and $\mathrm{n}=$ number of experiments. Data were transformed back to the linear scale for presentation.

Efficacies were calculated according to Abbott ${ }^{22}$ as $\left(1-\left(D_{I} S_{\text {ind }} \times\right.\right.$ DIS $\left.\left._{\text {mean }}\right)\right) \times 100$, with DIS ind $=$ disease level of an individual treated plant and $\mathrm{DIS}_{\text {mean }}=$ mean disease level of non-treated control plants.

$E_{50}$ values of LAR-016 and of pure larixol and larixyl acetate were calculated according to Alexander et al. as follows: EC50 $=$ ConcA $-\frac{(\mathrm{A}-50 \% \text { max response }) \times(\text { ConcA-ConcB })}{A-B}$, with $A$ and $B$ the nearest actually recorded responses on either side of $50 \%$ the maximal response $(A>$ $50 \%, \mathrm{~B}<50 \%$ ) and ConcA and ConcB the corresponding concentrations, with maximal responses set to $100 \%$ for all experiments. ${ }^{23}$ 
Area under disease progress curves (AUDPC) were calculated as $A U D P C=$

$\sum_{i=1}^{n-1} \frac{y_{i}+y_{i+1}}{2} \times\left(t_{i+1}-t_{i}\right)$, where $y_{i}$ is disease severity at the $\mathrm{i}^{\text {th }}$ observation, $\mathrm{t}_{\mathrm{i}}$ is date at the $\mathrm{i}^{\text {th }}$ observation, and $\mathrm{n}$ is the total number of observations.

Percentage data from field experiments were arcsin-transformed as follows: $\arcsin \left(\right.$ squareroot $\left(\right.$ SEV $\left.\left.\times 100^{-1}\right)\right)$, with SEV = disease severity in \%. AUDPC data were logtransformed before statistical analysis. Homogeneity of variances was verified using Levene's test before analysis. ANOVA ( $\alpha=5 \%)$ with the factors variety, treatment, block, and the interaction variety $\mathrm{x}$ treatment $(\mathrm{CH}-\mathrm{Frick})$ or the factors treatment and block (I-San Michele, GR-Veria) followed by a post-hoc Tukey-B test to compare individual treatments were performed. In case of non-significant variety $\mathrm{x}$ treatment interactions in $\mathrm{CH}$-Frick, data of the two varieties were pooled for presentation in tables and figures.

\subsection{RESULTS}

\subsection{Optimisation of extraction of the active compounds larixyl acetate and larixol}

To optimise extraction of the active compounds larixyl acetate and larixol from larch stem bark, efficacies of the solvents $\mathrm{CH}_{2} \mathrm{Cl}_{2}, \mathrm{MeOH}$ and EtOAc were first compared using small scale Soxhlet extraction. While EtOAc gave very low extraction yields, $\mathrm{CH}_{2} \mathrm{Cl}_{2}$ and $\mathrm{MeOH}$ both produced extracts containing larixyl acetate and larixol. The $\mathrm{MeOH}$ extract $(6.03 \%$ extraction yield) contained $0.63 \%$ larixyl acetate and $0.19 \%$ larixol, while the $\mathrm{CH}_{2} \mathrm{Cl}_{2}$ extract (2.12\% extraction yield) contained $4.37 \%$ larixyl acetate and $0.31 \%$ larixol (Tab. 1$)$.

The percentage of the combined actives (larixyl acetate plus larixol) extracted from the stem bark was $0.099 \%$ with $\mathrm{CH}_{2} \mathrm{Cl}_{2}$ and $0.049 \%$ with $\mathrm{MeOH}$, to give a total of $0.15 \%$ actives from the bark. If sequential extraction $\left(\mathrm{CH}_{2} \mathrm{Cl}_{2}\right.$ followed by $\left.\mathrm{MeOH}\right)$ was used, the total percentage actives was approximately the same at $0.14 \%$. (Tab. 1 ).

In order to avoid the use of chlorinated solvents, methanol was selected for large scale extraction to produce $1.3 \mathrm{~kg}$ extract from $18.5 \mathrm{~kg}$ of larch bark for the year 1 field season. The 
yield of this extract was $7.02 \%$ containing $0.051 \%$ of the combined actives from the bark (Tab. 1).

To develop an upscalable method for production of a plant protection product suitable for the organic farming market, a range of solvents thought to be economically feasible and respecting safety regulations (explosion hazard, flammability, toxicity, environmental impact, residues), including ethanol, water (cold and hot) and ethanol-water mixtures (cold and hot) were evaluated (Tab. 2). Yields of $0.066 \%$ larixyl acetate and $0.016 \%$ larixol were obtained extracting $10 \mathrm{~mm}$ sieved sample with $\mathrm{EtOH}$, which were comparable to acetone or petroleum ether extracts (Tab. 2). In contrast, water gave very poor yields of the combined actives (< 0.002-0.008\%), while EtOH- $\mathrm{H}_{2} \mathrm{O}$ mixtures were intermediate $(0.016-0.039 \%)$. Particle size had an impact on yields, with larger particles giving higher yields of the two actives than smaller particles.

To obtain extracts with higher concentrations of the two actives, extracts were re-extracted with petroleum ether to remove sugars, and results are presented in Tab. 3. Two selected EtOH:water extracts were separately treated with the amine 2-amino-2-methyl-1-propanol (AMP) in order to remove diterpene acids (Tab. 4). Concentrations of the actives in the EtOH:water extracts after treatment with AMP reached up to $30.5 \%$ for larixyl acetate and $8.5 \%$ for larixol, giving a total of $39.0 \%$ in the extract (Tab. 4 ).

To find alternative sources for larixyl acetate and larixol, larch turpentine was investigated. Larch turpentine is gained from $L$. decidua trees by drilling holes into trunks and collecting the accumulated oleoresin. ${ }^{24}$ Purchased larch turpentine contained $31.2 \%$ larixyl acetate and $5.3 \%$ larixol (36.5\% combined actives) (Tab. 5). Larch oleoresin was slightly toxic to small grapevine plants, causing some necrotic areas, especially on young leaves (data not shown). After removal of the diterpene acids using AMP, concentrations of larixyl acetate and larixol were $58.8 \%$ and $7.7 \%$ respectively $(66.5 \%$ combined actives $)$ and the resulting extract was non-toxic to seedlings (data not shown). This extract was formulated for use in year 1 and year 2 field trials (LAR-016, LAR-042). 


\subsection{Fungicidal activity of larch turpentine extract and the active compounds larixol and larixyl acetate under semi-controlled conditions}

In order to be able to compare fungicidal activity of larch extracts and its active compounds to other botanicals or natural compounds, minimal inhibitory concentrations and effective concentrations were determined. Minimal concentrations to completely inhibit germination and/or growth of zoospores of $P$. viticola $\left(\mathrm{MIC}_{100}\right)$ were evaluated in in vitro bioassays. All experiments were performed using larch turpentine extract. To improve water solubility, larch turpentine extract was tested as a formulated product (LAR-016). The mean minimal concentration needed to completely inhibit zoospore germination and/or activity was $23 \mu \mathrm{g}$ plant extract $\mathrm{mL}^{-1}$ in formulation LAR-016 (Tab. 6), containing $15 \mu \mathrm{g} \mathrm{mL}^{-1}$ equivalents of the two combined active compounds. The blank formulation LAR-016 (only containing additives) did not inhibit $P$. viticola in vitro. Mean $\mathrm{MIC}_{100}$ of the active compounds larixyl acetate and larixol were $6 \mu \mathrm{g} \mathrm{mL}^{-1}$ or $14 \mu \mathrm{g} \mathrm{mL}^{-1}$, respectively, with very low variability between experiments.

Activities of larch extract and the active compounds against grapevine downy mildew caused by $P$. viticola was evaluated in planta in dose-response experiments on small susceptible grapevine plants (cv. 'Chasselas') under semi-controlled conditions. The efficacy of the larch turpentine extract (in formulation LAR-016) was very high in both experiments, with efficacies $\geq 99 \%$ at concentrations between 0.5 and $1 \mathrm{mg}$ plant extract $\mathrm{mL}^{-1}$ at very high disease pressures (Fig. 3). In both experiments, $\mathrm{EC}_{50}$ was $0.2 \mathrm{mg}$ plant extract $\mathrm{mL}^{-1}$, containing 0.14 $\mathrm{mg} \mathrm{mL}^{-1}$ equivalents of the two combined active compounds. The blank formulation of LAR016 tested at concentrations contained in formulations of $2 \mathrm{mg}$ plant extract $\mathrm{mL}^{-1}$ never showed any significant inhibitory effect (data not shown). Solubility of pure compounds in water was limited, but the development of a formulation was not possible due to low availability of compounds. Larixyl acetate reached efficacies $\geq 89 \%$ at concentrations of 0.5

(Fig. 4C, 4D) or $1 \mathrm{mg} \mathrm{mL}^{-1}$ (Fig. 4A) in three experimental sets. In a fourth experiment, a maximum of $74 \%$ efficacy was reached at $1 \mathrm{mg} \mathrm{mL}^{-1}$, the highest concentration tested. (Fig. 3B). Efficacy of larixol reached 90\% (Fig 4A) and 78\% (Fig. 4B) at the highest tested 
concentration $\left(1 \mathrm{mg} \mathrm{mL}^{-1}\right)$. A mixture of larixyl acetate $(84 \%)$ and larixol $(16 \%)$ in ratios as found in larch turpentine extracts showed a dose-response curve comparable to the pure compounds. $\mathrm{EC}_{50}$ of larixyl acetate were $0.13-0.23 \mathrm{mg} \mathrm{mL}^{-1}$ (three out of four experiments, Fig. 4A, 4C, 4D) and $0.69 \mathrm{mg} \mathrm{mL}^{-1}$ (Fig. 4B). EC 50 of larixol (0.20 (Fig. 4A) and 0.59 (Fig. 4B) $\mathrm{mg} \mathrm{mL}^{-1}$ ) and of mixtures of larixyl acetate and larixol (0.21 (Fig. 4A) and 0.30 (Fig. 4B) mg $\mathrm{mL}^{-1}$ ) were comparable to larixyl acetate within individual experiments.

\subsection{Activity of larch extracts under field conditions}

\subsubsection{Development of epidemics}

In 2014 in CH-Frick, due to warm and dry conditions from Mid-May until end of June, disease pressure of grapevine downy mildew caused by $P$. viticola was relatively low in the primary season, but favoured development of powdery mildew caused by E. necator. The first major infection period for grapevine downy mildew occurred at the beginning of June 2014 and resulted in few first lesions in Mid-June. During August 2014, grapevine downy mildew developed rapidly such that by the end of August, disease incidence was up to $100 \%$ (data not shown) and severity about 50\% (Fig. 5A).

In 2015, in all three trials in different geographic regions, disease pressure was low to moderate due to relatively dry and hot weather conditions. In $\mathrm{CH}$-Frick, the first visible grapevine downy mildew symptoms appeared in the beginning of June. Until the end of June, the degree of infection progressed quite rapidly. The warm and dry weather conditions during July and August slowed down the infection progress. By the end of August 2015, disease incidence and severity in the non-treated control reached approximately $50 \%$ (data not shown) and 9\%, respectively (Fig. 5B). In I-San Michele, in May and June 2015, there was only sporadic rainfall, and July was characterized by particularly warm and dry weather conditions, which were followed by fairly wet conditions in August and September, resulting in a moderate grapevine downy mildew disease pressure, with $82 \%$ disease incidence (data not shown) and $14 \%$ disease severity on leaves of the non-treated control at the end of the season (Fig. 5C). In GR-Veria, disease onset in 2015 was delayed due to warm and dry 
weather conditions and the first symptoms of the disease were observed in early July. At the end of the season, disease incidence of the non-treated control reached $42 \%$ (data not shown) and severity 33\% (Fig. 5C). In all trials, the references (copper, Strategy) protected grapevine plants very efficiently from grapevine downy mildew (86-94\% reduction of infected leaf area) (Fig. 5).

\subsubsection{Efficacy of test products}

Efficacy of larch extracts was evaluated under field conditions in four independent trials under three different climatic conditions in two field seasons. Since extraction and formulation were subject to an optimization process, three formulations based on two different extracts were used at different concentrations. In all four field trials, all formulations significantly reduced grapevine downy mildew compared to the non-treated control at the end of the season (ANOVA at $\alpha=5 \%$ on arcsin-transformed data, followed by a post-hoc Tukey-B test to compare individual treatments)(Fig. 5). In 2014, LAR-016 based on larch turpentine extract reduced leaf area infected with grapevine downy mildew on leaves by $49 \%$ compared to the non-treated control in $\mathrm{CH}$-Frick at the end of the season (Fig. 5A). The second formulation evaluated in 2014, LAR-024 based on a larch bark extract, reduced disease severity on leaves to a similar extent. In 2015, treatment with LAR-016 reduced leaf area infected with P. viticola at the end of the season by 58\% (CH-Frick) (Fig. 5B), 76\% (I-San Michele)(Fig. 5C) or 82\% (GR-Veria)(Fig. 5D). LAR-042, a second formulation based on the same extract, reduced disease severity on leaves by 68\% in $\mathrm{CH}$-Frick in 2015 (Fig. 5B). In $\mathrm{CH}$-Screening, where powdery mildew caused by E. necator was not controlled by application of synthetic fungicides, percentage leaf area infected by $E$. necator was significantly reduced by LAR-016 by $96 \%$ (2014) and $88 \%$ (2015), by LAR-042 by $85 \%$ (2015), and by LAR-024 by $88 \%$ (2014) compared to the non-treated control (ANOVA at $\alpha=5 \%$ on arcsin-transformed data, followed by a post-hoc Tukey-B test to compare individual treatments)(Tab.7). 


\section{DISCUSSION and CONCLUSIONS}

Larch extract and its active compounds larixyl acetate and larixol showed high efficacies against $P$. viticola in vitro and in planta under semi-controlled conditions at low concentrations ( $\mathrm{MIC}_{100}$ of 6-24 $\mu \mathrm{g} \mathrm{mL}^{-1}$ and $\mathrm{EC}_{50}$ of $0.1-0.6 \mathrm{mg} \mathrm{mL}^{-1}$ ), which is one of several prerequisites of an economically viable plant protection product based on plant extracts. Other plant extracts were comparable at similar concentrations, for example Juncus effusus (common rush) extract and its active ingredient DHEF, ${ }^{11}{ }^{7}$ extracts of Abies sibirica (Siberian fir), Inula viscosa (false yellowhead), Yucca schidigera (Mojave yucca), Melaleuca alternifolia (narrow-leaved tea-tree), and Quillaja saponaria (soapbark), whereas 10 to 50 times higher concentrations were necessary for extracts of Glycyrrhiza glabra (Liquorice), Salvia officinalis (sage), Solidago virgaurea (European goldenrod) or Rheum rhabarbarum (rhubarb). ${ }^{7}$ Larch extracts were efficient to control $P$. viticola not only under controlled, but also under field conditions. When applied as a stand-alone strategy in a screening vineyard in CH-Frick, efficacies up to $68 \%$ were reached. In former studies, only two extracts (Melaleuca alternifolia, Salvia officinalis) had reached similar efficacies in the same screening vineyard, while most other tested plant extracts (Inula viscosa, Abies sibirica, Quillaja saponaria, Camellia oleifera) were less efficient. ${ }^{7,25}$ Yet, efficacy of larch extracts alone was lower than efficacy of the references (copper, strategy). Disease pressure in the experimental vineyard $\mathrm{CH}-\mathrm{Frick}$ is in general very severe owing to highly infected non-treated control plants standing close to treated plants. When larch extract was used in a strategy with a limited amount of copper applied to all plants during high-risk infection periods around bloom to reduce overall disease pressure (I-San Michele, GR-Veria), larch extract reached efficacies up to $82 \%$, demonstrating the potential in a low copper strategy. The situation in I-San Michele is representative for the situation in commercial vineyards when no advanced decision support systems are available and sprays are conducted at fixed intervals. Larch extracts were not only active against downy, but also against powdery mildew of grapevine, which is highly advantageous in regions where both pathogens occur simultaneously, allowing to avoid or reduce additional treatments against powdery mildew. 
Optimised extraction processes as well as high availability and low price of raw material are of crucial importance for the economic viability of botanical plant protection products. For example, low extraction yields and/or high costs combined with limited availability of of raw material prevented further development of extracts of Rheum rhabarbarum ${ }^{7}$ and Juncus effusus $^{11}$ despite their excellent efficacies. In the present study we have shown that both the bark of $L$. decidua and larch turpentine are suitable materials for the production of a standardized larch extract. Environmentally friendly extraction methods suitable for both sources have been developed. $\mathrm{EtOH}$ and $\mathrm{H}_{2} \mathrm{O}-\mathrm{EtOH}$-mixtures were found to be the most suitable solvents for industrial scale extraction from the bark. It has been shown that particle size can affect yields, with larger particle size giving higher yields, probably due to improved mobility of solvents, possibly because milling to $4 \mathrm{~mm}$ produced a sticky bark material. In conclusion, we have shown that larch extracts containing the active ingredients larixyl acetate and larixol represent valid candidates for copper reduction in organic vineyards.

\section{Acknowledgements}

We gratefully acknowledge financial support by the EC through Grant Agreement Number 613600, ProLarix. Emily James acknowledges financial support from the University of

Surrey.

\section{REFERENCES}

1. Gessler C, Pertot I and Perazzolli M, Plasmopara viticola: a review of knowledge on downy mildew of grapevine and effective disease management. Phytopathol Mediterr 50(1): 3-44 (2011).

2. Speiser B, Mieves E and Tamm L, Kupfereinsatz von Schweizer Biobauern in verschiedenen Kulturen. Agrarforschung Schweiz 6(4): 160-165 (2015).

3. Brun LA, Maillet J, Richarte J, Herrmann P and Remy JC, Relationships between extractable copper, soil properties and copper uptake by wild plants in vineyard soils. Environment Pollut 102(2): 151-161 (1998).

4. Pietrzak $U$ and McPhail D, Copper accumulation, distribution and fractionation in vineyard soils of Victoria, Australia. Geoderma 122(2): 151-166 (2004). 
5. Kula $\mathrm{C}$ and Guske $\mathrm{S}$, Auswirkungen von Kupfer auf Bodenorganismen bei langjähriger Anwendung. Berichte aus der Biologischen Bundesanstalt 118: 11-16 (2003).

6. Tamm L and Speiser B. Direct control of airborne diseases. In Plant diseases and their management in organic agriculture, ed. by Finckh MR, van Bruggen AH and Tamm L. APS Press, St. Paul, Minnesota, USA (2015).

7. Dagostin S, Schärer H-J, Pertot I and Tamm L, Are there alternatives to copper for controlling grapevine downy mildew in organic viticulture? Crop Prot 30(7): 776-788 (2011).

8. Scherf A, Treutwein J, Kleeberg $\mathrm{H}$ and Schmitt A, Efficacy of leaf extract fractions of Glycyrrhiza glabra L. against downy mildew of cucumber (Pseudoperonospora cubensis). Europ J Plant Pathol 134(4): 755-762 (2012).

9. Cohen Y, Wang W, Ben-Daniel B-H and Ben-Daniel Y, Extracts of Inula viscosa control downy mildew of grapes caused by Plasmopara viticola. Phytopathol 96(4): 417-424 (2006).

10. Schnee S, Queiroz EF, Voinesco F, Marcourt L, Dubuis P-H, Wolfender J-L and Gindro K, Vitis vinifera canes, a new source of antifungal compounds against Plasmopara viticola, Erysiphe necator, and Botrytis cinerea. J Agric Food Chem 61(23): 5459-5467 (2013).

11. Thuerig B, Ramseyer J, Hamburger M, Oberhänsli T, Potterat O, Schärer HJ and Tamm L, Efficacy of a Juncus effusus extract on grapevine and apple plants against Plasmopara viticola and Venturia inaequalis, and identification of the major active constituent. Pest Manag Sci 72(9): 1718-1726 (2016).

12. Puopolo G, Cimmino A, Palmieri MC, Giovannini O, Evidente A and Pertot I, Lysobacter capsici AZ78 produces cyclo(I-Pro-I-Tyr), a 2,5-diketopiperazine with toxic activity against sporangia of Phytophthora infestans and Plasmopara viticola. J Appl Microbiol 117(4): 1168-1180 (2014).

13. Puopolo G, Giovannini O and Pertot I, Lysobacter capsici AZ78 can be combined with copper to effectively control Plasmopara viticola on grapevine. Microbiol Res 169(7): 633-642 (2014).

14. Mulholland DA, Thuerig B, Langat MK, Tamm L, Nawrot DA, James EE, Qayyum M, Shen D, Heap K, Jones A, Hokkanen H, Demidova N, Izotov D and Schärer H-J, The phytochemistry of eight forestry species and their activity against Plasmopara viticola. Crop Protsubmitted).

15. Mantau U, Saal U, Prins K, Steierer F, Lindner M, Verkerk H, Eggers J, Leek N, Oldenburger J and Asikainen A. EUwood - Real potential for changes in growth and use of EU forests. Final Report. Hamburg, pp. 160 (2010).

16. Ehlers R-U (ed.). Regulation of biological control agents. Springer, Dordrecht, Heidelberg, London, New York, pp. 416 (2011).

17. Da Ronch F, Caudullo G, Tinner W and de Rigo D. Larix decidua and other larches in Europe: distribution, habitat, usage and threats. In European atlas of forest tree species, ed. by SanMiguel-Ayanz J, de Rigo D, Caudullo G, Houston Durrant T and Mauri A. Publication Office of the European Union, Luxembourg (2016).

18. EPPO, Plasmopara viticola. EPPO Bulletin 31(2): 313-317 (2001).

19. Häseli A, Tamm L and Wyss E. Krankheits- und Schädlingsregulierung im biologischen Rebbau. Research Institute of Organic Agriculture, Frick, Switzerland, pp. 16 (1999).

20. Tamm L, Fuchs JG, Böger N, Mühletaler L, Amsler T, Levite D and Häseli A. Properties of acidified clay preparations: the Swiss experience. In Symposium für ökologischen Weinbau Intervitis Stuttgart, pp. 27-36 (12.-13. Mai 2004).

21. Small IM, Joseph L and Fry WE, Development and implementation of the BlightPro decision support system for potato and tomato late blight management. Computers and Electronics in Agriculture 115: 57-65 (2015).

22. Abbott WS, A method for computing the effectiveness of an insecticide. J Econ Entomol 18: 265-267 (1925).

23. Alexander B, Browse DJ, Reading SJ and Benjamin IS, A simple and accurate mathematical method for calculation of the EC50. J Pharmacol Toxicol Methods 41(2-3): 55-58 (1999).

24. Lagoni N, Vom Lärchenharz zum Terpentin bis Lärchenöl. Wissen 69: 79-81 (2012).

25. Dagostin S, Formolo T, Giovannini O, Pertot I and Schmitt A, Salvia officinalis extract can protect grapevine against Plasmopara viticola. Plant Dis 94(5): 575-580 (2010). 
Table 1. Yield and chemical composition of extracts obtained after extracting stem bark of Larix decidua with different solvents using Soxhlet extraction.

\begin{tabular}{|c|c|c|c|c|c|c|c|}
\hline \multirow[t]{2}{*}{ Method of extraction } & \multirow[t]{2}{*}{ Solvent } & \multirow{2}{*}{$\begin{array}{l}\text { Extract } \\
\text { yield } \\
\text { from } \\
\text { stem } \\
\text { bark }(\%) \\
\end{array}$} & \multicolumn{2}{|c|}{$\begin{array}{l}\text { Content in } \\
\text { extract }(\%)\end{array}$} & \multicolumn{3}{|c|}{ Yield from stem bark (\%) } \\
\hline & & & $\begin{array}{l}\text { Larixyl } \\
\text { acetate }\end{array}$ & Larixol & $\begin{array}{l}\text { Larixyl } \\
\text { acetate }\end{array}$ & Larixol & $\begin{array}{c}\text { Combined } \\
\text { actives }\end{array}$ \\
\hline Separate extraction & $\mathrm{CH}_{2} \mathrm{Cl}_{2}$ & 2.12 & 4.37 & 0.31 & 0.093 & 0.007 & 0.099 \\
\hline \multirow[t]{2}{*}{ small scale $^{\dagger}$} & $\mathrm{MeOH}$ & 6.03 & 0.63 & 0.19 & 0.038 & 0.011 & 0.049 \\
\hline & EtOAc & $0.002 \S$ & - & - & - & - & - \\
\hline Total & & & & & & & 0.15 \\
\hline \multirow[t]{2}{*}{ Successive extraction } & $\mathrm{CH}_{2} \mathrm{Cl}_{2}$ & 2.12 & 4.37 & 0.31 & 0.093 & 0.007 & 0.099 \\
\hline & $\begin{array}{c}\mathrm{MeOH} \text { after } \\
\mathrm{CH}_{2} \mathrm{Cl}_{2}\end{array}$ & 1.32 & 2.43 & 0.70 & 0.032 & 0.009 & 0.041 \\
\hline Total & & 3.44 & & & 0.125 & 0.016 & 0.14 \\
\hline Large scale $^{\ddagger}$ & $\mathrm{MeOH}$ & 7.02 & 0.58 & 0.14 & 0.041 & 0.010 & 0.051 \\
\hline
\end{tabular}

$\uparrow 100 \mathrm{~g}$ bark; ${ }^{\ddagger} 18.5 \mathrm{~kg}$ bark to produce extract for field season $2014 ;{ }^{\S}$ Low yield, not further analysed. 
Table 2. Yield and chemical composition of extracts obtained by agitating milled stem bark of Larix decidua for eight hours with different solvents at room temperature (RT) or at $100^{\circ} \mathrm{C}$.

\begin{tabular}{|c|c|c|c|c|c|c|c|}
\hline \multirow[t]{2}{*}{ Solvent } & \multirow[t]{2}{*}{$\begin{array}{l}\text { Extraction } \\
\text { temperature }\end{array}$} & \multirow{2}{*}{$\begin{array}{c}\text { Particle } \\
\text { size } \\
(\mathrm{mm})\end{array}$} & \multirow{2}{*}{$\begin{array}{c}\text { Extract yield } \\
\text { from stem } \\
\text { bark (\%) }\end{array}$} & \multicolumn{2}{|c|}{$\begin{array}{l}\text { Content in } \\
\text { extract (\%) }\end{array}$} & \multicolumn{2}{|c|}{$\begin{array}{l}\text { Yield from stem } \\
\text { bark (\%) }\end{array}$} \\
\hline & & & & $\begin{array}{l}\text { Larixyl } \\
\text { acetate }\end{array}$ & Larixol & $\begin{array}{l}\text { Larixyl } \\
\text { acetate }\end{array}$ & Larixol \\
\hline Acetone & $\mathrm{RT}+$ & 4 & 2.19 & 3.00 & 0.72 & 0.066 & 0.016 \\
\hline PE $\ddagger$ & RT & 4 & 0.57 & 13.82 & 2.99 & 0.079 & 0.017 \\
\hline & RT & 4 & 1.58 & 1.01 & 0.28 & 0.016 & 0.004 \\
\hline $\mathrm{EtOH}$ & RT & 10 & 2.61 & 2.51 & 0.62 & 0.066 & 0.016 \\
\hline $\mathrm{H}_{2} \mathrm{O}$ & RT & 4 & 0.82 & $<0.11$ & 0.17 & $<0.001$ & 0.001 \\
\hline $\mathrm{H}_{2} \mathrm{O}$ & $100^{\circ} \mathrm{C}$ & 4 & 4.15 & $<0.07$ & 0.11 & $<0.003$ & 0.005 \\
\hline $\mathrm{EtOH}: \mathrm{H}_{2} \mathrm{O}$ & RT & 4 & 7.09 & 0.14 & 0.09 & 0.010 & 0.006 \\
\hline $1: 1$ & RT & 10 & 4.22 & 0.35 & 0.18 & 0.015 & 0.008 \\
\hline $\begin{array}{l}\text { EtOH: } \mathrm{H}_{2} \mathrm{O} \\
1: 1\end{array}$ & $100^{\circ} \mathrm{C}$ & 4 & 7.12 & 0.42 & 0.13 & 0.030 & 0.009 \\
\hline
\end{tabular}


Table 3: Yield and chemical composition of extracts gained by re-extracting different Larix decidua stem bark extracts with petroleum ether.

\begin{tabular}{|c|c|c|c|c|c|c|c|}
\hline \multicolumn{4}{|c|}{ Initial extract } & \multicolumn{4}{|c|}{ Petroleum ether extract } \\
\hline \multirow{2}{*}{$\begin{array}{l}\text { Solvent } \\
\text { initial } \\
\text { extract }\end{array}$} & \multirow{2}{*}{$\begin{array}{c}\text { Extraction } \\
\text { temperature }\end{array}$} & \multirow{2}{*}{$\begin{array}{c}\text { Particle } \\
\text { size } \\
(\mathrm{mm})\end{array}$} & \multirow{2}{*}{$\begin{array}{c}\text { Yield } \\
\text { from } \\
\text { stem } \\
\text { bark (\%) }\end{array}$} & \multirow{2}{*}{$\begin{array}{l}\text { Yield from } \\
\text { initial } \\
\text { extract (\%) }\end{array}$} & \multirow{2}{*}{$\begin{array}{c}\text { Yield } \\
\text { from } \\
\text { stem } \\
\text { bark (\%) }\end{array}$} & \multicolumn{2}{|c|}{ Composition (\%) } \\
\hline & & & & & & $\begin{array}{l}\text { Larixyl } \\
\text { acetate }\end{array}$ & Larixol \\
\hline Acetone & $\mathrm{RT}^{\dagger}$ & 4 & 2.19 & 0.06 & 0.001 & 61.97 & 8.09 \\
\hline \multirow[t]{2}{*}{$\mathrm{EtOH}$} & RT & 4 & 1.58 & 6.70 & 0.11 & 3.72 & 0.86 \\
\hline & RT & 10 & 2.61 & 16.92 & 0.44 & 13.02 & 2.68 \\
\hline \multirow[t]{2}{*}{$\mathrm{H}_{2} \mathrm{O}$} & RT & 4 & 0.82 & 0.05 & 0.001 & 2.74 & 2.59 \\
\hline & $100^{\circ} \mathrm{C}$ & 4 & 4.15 & 0.06 & 0.002 & 2.49 & $<1.50$ \\
\hline \multirow{3}{*}{$\begin{array}{l}\text { EtOH:water } \\
1: 1\end{array}$} & RT & 4 & 7.09 & 1.01 & 0.07 & 14.56 & 3.46 \\
\hline & RT & 10 & 4.22 & 2.70 & 0.11 & 17.36 & 5.5 \\
\hline & $100^{\circ} \mathrm{C}$ & 4 & 7.12 & 0.40 & 0.03 & 7.83 & 2.93 \\
\hline
\end{tabular}

${ }^{\dagger}$ Room temperature; 
Table 4: Yield and chemical composition of extracts gained by precipitating diterpene acids with 2-Amino-2-methyl-1-propanol (AMP) from two Larix decidua stem bark extracts of different particle size.

\begin{tabular}{|c|c|c|c|c|c|c|c|c|c|}
\hline \multicolumn{4}{|c|}{ Initial extract } & \multicolumn{6}{|c|}{ AMP extract } \\
\hline \multirow{2}{*}{$\begin{array}{l}\text { Solvent } \\
\text { initial } \\
\text { extract }\end{array}$} & \multirow[t]{2}{*}{$\begin{array}{l}\text { Extraction } \\
\text { temperature }\end{array}$} & \multirow{2}{*}{$\begin{array}{c}\text { Particle } \\
\text { size } \\
(\mathrm{mm})\end{array}$} & \multirow{2}{*}{$\begin{array}{l}\text { Yield } \\
\text { from } \\
\text { stem } \\
\text { bark } \\
(\%)\end{array}$} & \multirow{2}{*}{ 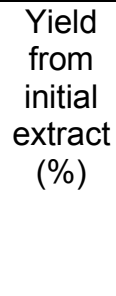 } & \multirow{2}{*}{$\begin{array}{c}\text { Yield } \\
\text { from } \\
\text { stem } \\
\text { bark } \\
(\%)\end{array}$} & \multicolumn{2}{|c|}{$\begin{array}{c}\text { Composition } \\
(\%)\end{array}$} & \multicolumn{2}{|c|}{$\begin{array}{l}\text { Yield from stem } \\
\text { bark (\%) }\end{array}$} \\
\hline & & & & & & $\begin{array}{l}\text { Larixyl } \\
\text { acetate }\end{array}$ & Larixol & $\begin{array}{l}\text { Larixyl } \\
\text { acetate }\end{array}$ & Larixo \\
\hline \multirow{2}{*}{$\begin{array}{l}\text { EtOH:water } \\
1: 1\end{array}$} & $\mathrm{RT}^{\dagger}$ & 4 & 7.09 & 0.16 & 0.011 & 30.53 & 8.45 & 0.003 & 0.001 \\
\hline & RT & 10 & 4.22 & 1.59 & 0.067 & 22.78 & 4.36 & 0.015 & 0.003 \\
\hline
\end{tabular}

Table 5. Composition of larch turpentine before and after removal of diterpene acids by reaction with 2-amino-2-methyl-1-propanol (AMP).

\begin{tabular}{lccccc}
\hline Turpentine & $\begin{array}{c}\text { Yield from } \\
\text { turpentine (\%) }\end{array}$ & \multicolumn{3}{c}{ Chemical composition (\%) } \\
\cline { 3 - 6 } & & $\begin{array}{c}\text { Larixyl } \\
\text { acetate }\end{array}$ & Larixol & \multicolumn{2}{c}{$\begin{array}{c}\text { Other } \\
\text { constituents }\end{array}$} \\
\cline { 3 - 6 } & - & 31.24 & 5.33 & 10.87 & 52.56 \\
\hline $\begin{array}{l}\text { Before reaction with AMP } \\
\text { After reaction with AMP }\end{array}$ & 42 & 58.77 & 7.67 & 21.66 & 11.90 \\
(turpentine extract) & & & & & \\
\hline
\end{tabular}


Table 6. Minimal inhibitory concentrations $\left(\mathrm{MIC}_{100}\right)$ of a formulated larch turpentine extract (LAR-016), larixyl acetate, larixol, and solvent controls (blank formulation LAR-016, EtOH) against Plasmopara viticola in in vitro experiments.

\begin{tabular}{lcc}
\hline Product & $\mathrm{MIC}_{100}\left(\mu \mathrm{g} \mathrm{\textrm {mL } ^ { - 1 } )}\right.$ & $\mathrm{N} \S$ \\
\hline LAR-016 & $23^{\dagger}(14 ; 38)^{\ddagger}$ & 3 \\
Larixyl acetate & $6(4 ; 9)$ & 8 \\
Larixol & $14(9 ; 22)$ & 7 \\
Blank LAR-016 & $500(250 ; 1000)$ & 3 \\
EtOH & $250(163 ; 384)$ & 8
\end{tabular}

${ }^{\dagger}$ Mean; ${ }^{\ddagger}$ Upper and lower limits of the 95\% confidence interval; $§$ Number of independent experiments 
Table 7. Efficacy of formulated larch turpentine (LAR-016, LAR-042) or larch bark (LAR-024) extract against powdery mildew on grapevine leaves under field conditions in 2014 and 2015 in an experimental vineyard situated in Frick (Switzerland). Disease was assessed between end of July and end of August.

\begin{tabular}{|c|c|c|c|c|c|c|}
\hline \multirow[t]{2}{*}{ Year } & \multirow[t]{2}{*}{ Treatment } & \multirow{2}{*}{$\begin{array}{c}\text { Concentration } \\
\qquad\left(\mathrm{g} \mathrm{L}^{-1}\right)\end{array}$} & \multicolumn{2}{|c|}{ Severity $(\%)^{\ddagger}$} & \multirow{2}{*}{$\begin{array}{c}\text { Efficacy } \\
(\%)\end{array}$} & \multirow[t]{2}{*}{ Tukey-B ${ }^{+}$} \\
\hline & & & Mean $\S$ & SD & & \\
\hline \multirow[t]{5}{*}{2014} & Control & & 67 & 12 & & $a$ \\
\hline & $\mathrm{Cu}^{2+}$ & 0.5 & 0 & 0 & 100 & $b$ \\
\hline & Strategy ${ }^{\dagger}$ & & 0 & 0 & 100 & b \\
\hline & LAR-016 & 1 & 2.9 & 1.9 & 96 & bc \\
\hline & LAR-024 & $2-5$ & 8.5 & 4.2 & 87 & c \\
\hline \multirow[t]{5}{*}{2015} & Control & & 20.8 & 2.3 & & a \\
\hline & $\mathrm{Cu}^{2+}$ & 0.5 & 0.1 & 0.2 & 100 & $b$ \\
\hline & Strategy ${ }^{\dagger}$ & & 0.8 & 1.3 & 96 & b \\
\hline & LAR-016 & 2 & 1.2 & 0.9 & 94 & b \\
\hline & LAR-042 & 2 & 1.8 & 1.6 & 91 & $b$ \\
\hline
\end{tabular}

$\dagger$ Plant protection strategy recommended to Swiss organic grapevine producers (acidified clay minerals + sulphur); $\ddagger$ Percentage diseased leaf area ${ }^{\S}$ means and SD of four treatment replicates, each replicate consisting of 12 plants; ${ }^{+}$ANOVA on arcsin-transformed data followed by a post-hoc Tukey-B test, different letters indicating significant differences 


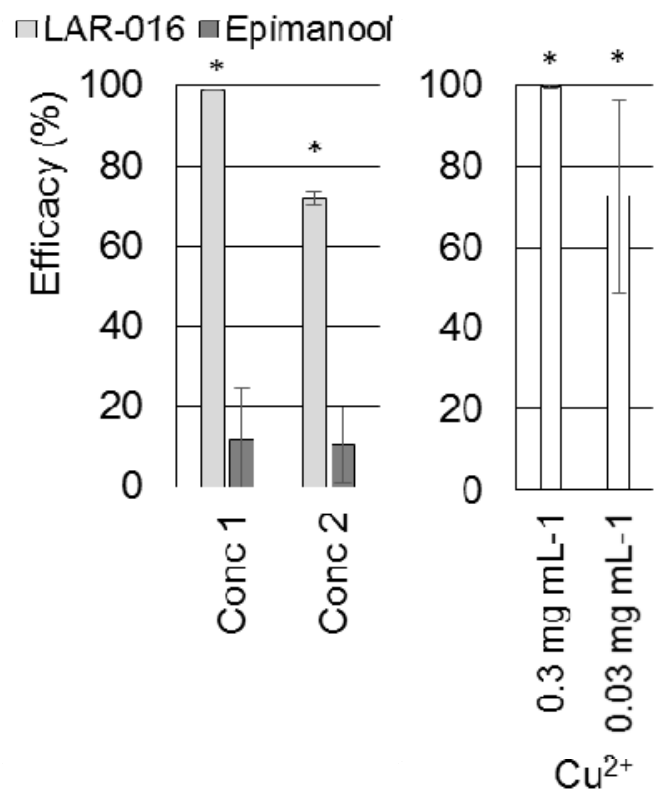

Figure 2. Efficacy of a formulated larch turpentine extract (LAR-016) and epimanool on grapevine seedlings against Plasmopara viticola. Epimanool was tested at concentrations corresponding to its content in larch turpentine extract (21\%). The experiment included two concentrations of a copper reference $\left(\mathrm{Cu}^{2+}\right)$. Mean disease severity of non-treated control was $94 \% \pm 10 \%$. The figure shows means and standard deviations $(n=6)$. 'Conc 1 ' $1 \mathrm{mg} \mathrm{mL}^{-1}$ larch turpentine extract or $0.21 \mathrm{mg} \mathrm{mL}^{-1}$ epimanool; 'Conc 2' $0.25 \mathrm{mg} \mathrm{mL}^{-1}$ larch turpentine extract or $0.05 \mathrm{mg} \mathrm{mL}^{-1}$ epimanool. Data were analysed by an ANOVA on arcsin-transformed data followed by a post-hoc Tukey-B test, $\left({ }^{*}\right)$ significantly different from control. 


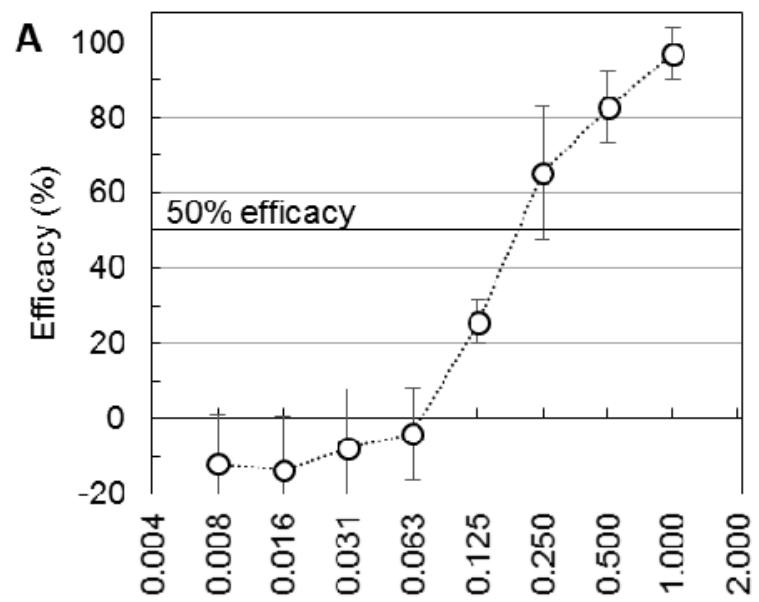

Concentration [mg mL-1]

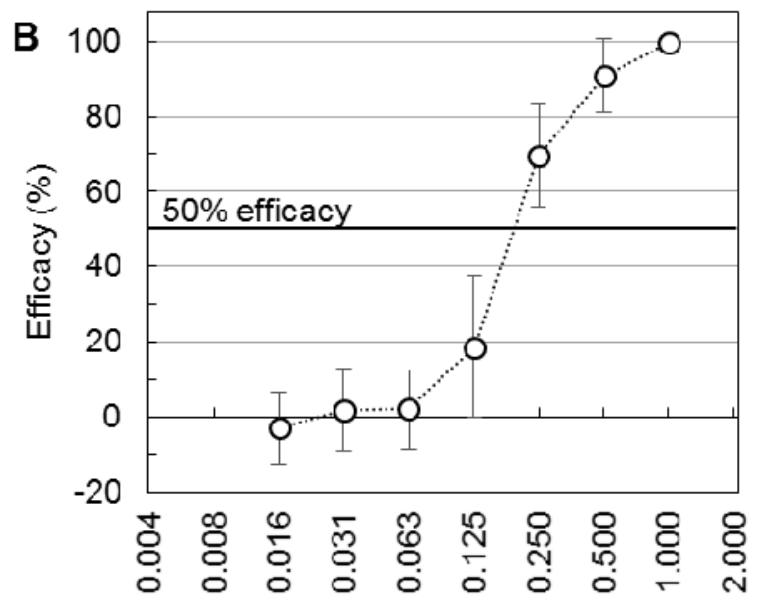

Concentration [mg mL-1]

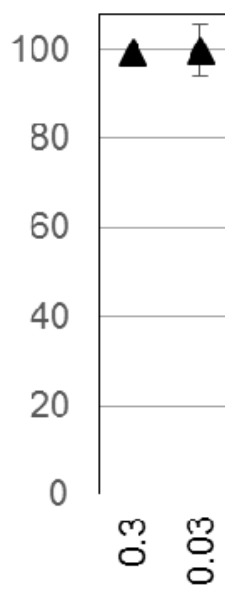

$\mathrm{Cu}^{21}$

[mg $\left.\mathrm{mL}^{-1}\right]$

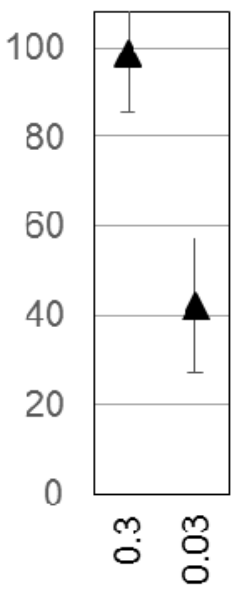

$\mathrm{Cu}^{++}$

$\left[\mathrm{mg} \mathrm{mL} \mathrm{L}^{-1}\right]$

Figure 3. Dose-response curves of a formulated larch turpentine extract (LAR-016) on grapevine seedlings against Plasmopara viticola. The figure shows results of two independent experiments $(A, B)$, with six individual plants per treatment and concentration (mean $\pm \mathrm{SD})$. Each experiment included two concentrations of a copper reference $\left(\mathrm{Cu}^{2+}\right)$. Mean disease severities of non-treated controls were $80 \% \pm 17 \%(A)$ and $93 \% \pm 12 \%(B)$. 
Figure 4. Dose-response curves of larixyl acetate, larixol and combinations thereof on grapevine seedlings against Plasmopara viticola. Compounds were tested in two (larixol, larixyl acetate + larixol) $(A, B)$ or four (larixyl acetate) (A-D) independent experiments. Each experiment included two concentrations of a copper reference $\left(\mathrm{Cu}^{2+}\right)$. Mean disease severities of non-treated controls were $93 \% \pm 6 \%(A), 81 \% \pm 10 \%(B)$,

inc $88 \% \pm 13 \%(C)$ and $91 \% \pm 8 \%(D)$. The figures show means and standard deviations $(n=6)$.

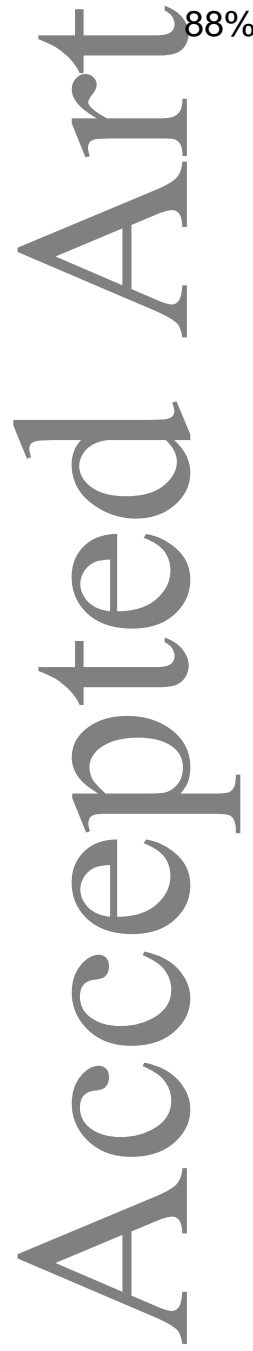



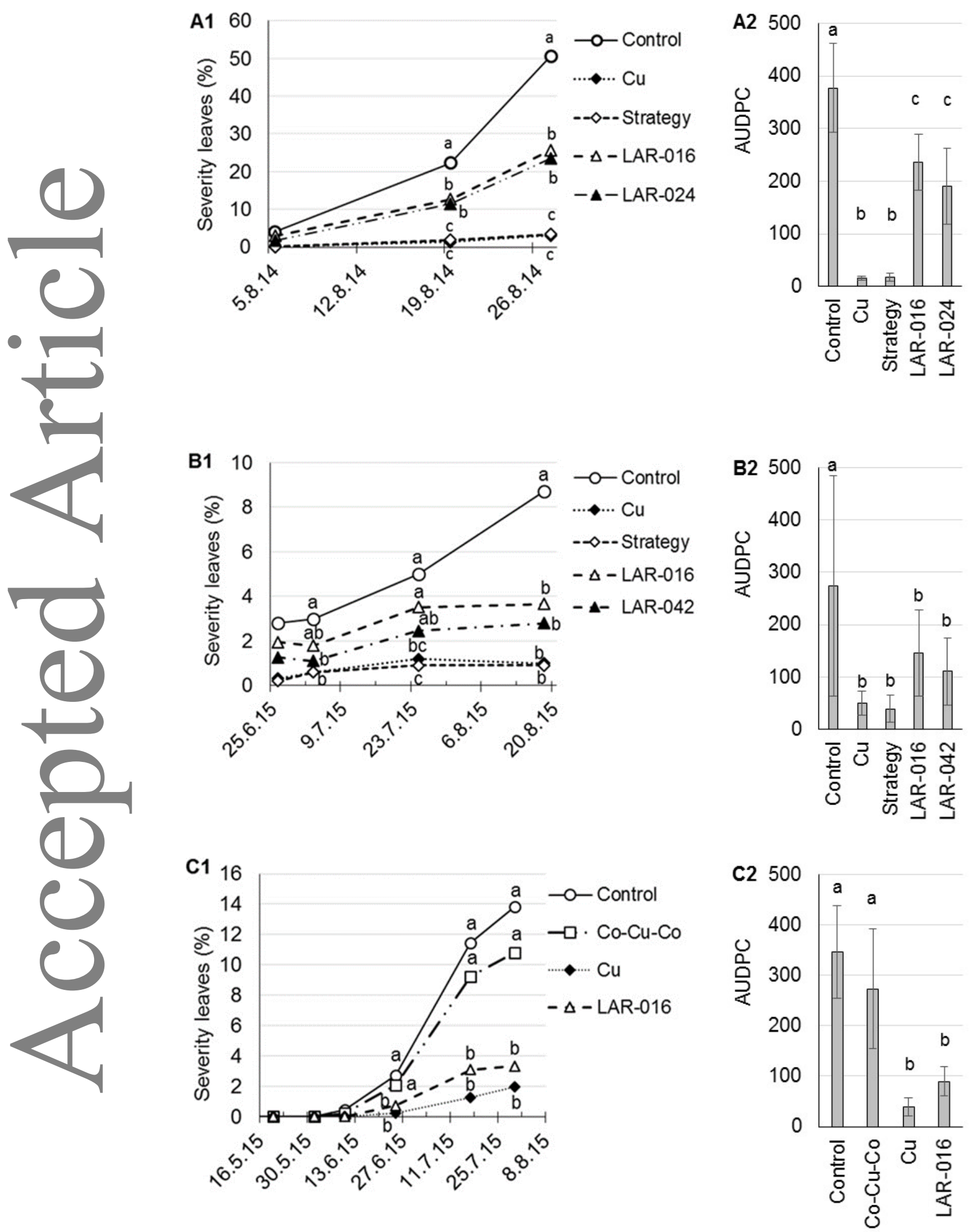

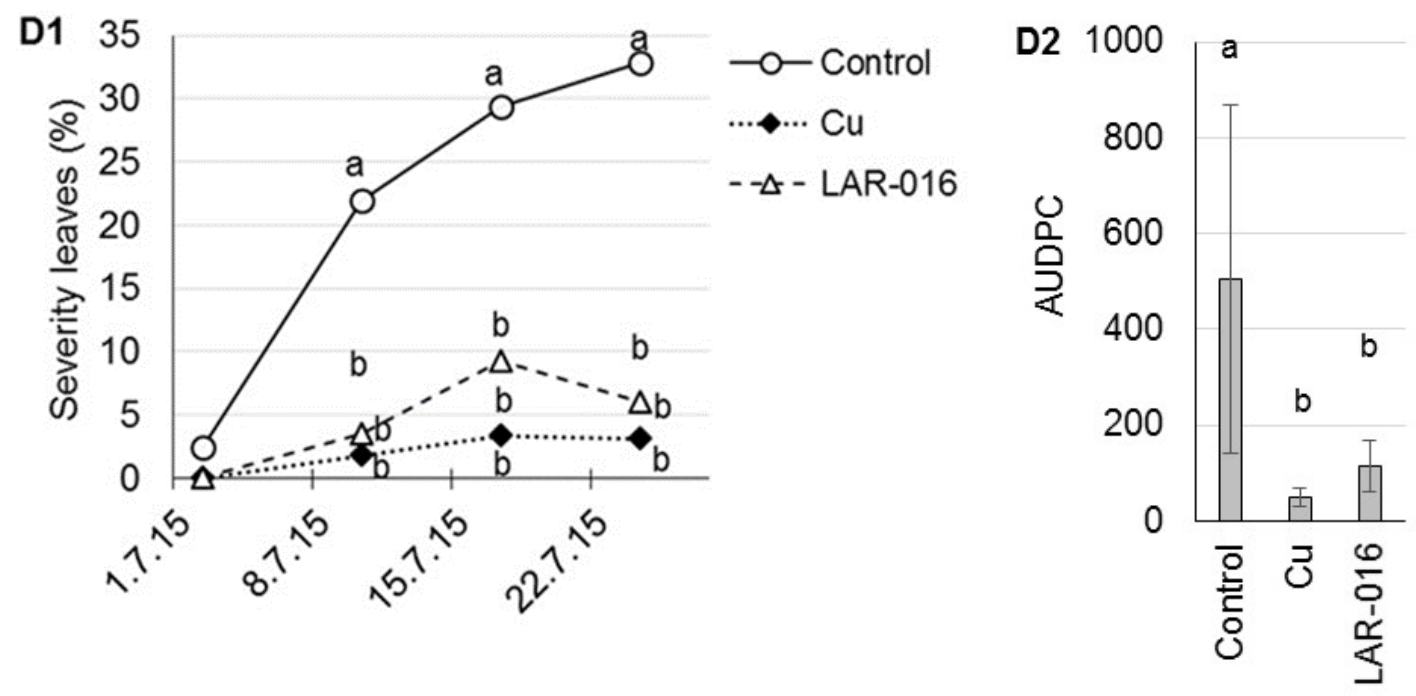

Figure 5: Disease development of grapevine downy mildew caused by $P$. viticola on leaves of plants treated with two formulations of a larch turpentine extract (LAR-016, LAR-042) or a formulated larch bark extract (LAR-024) in four independent field trials. All experiments were arranged in complete randomized block designs with four treatment replicates. The figures show mean percentage infected leaf area assessed at several timepoints (A1-D1) and the area

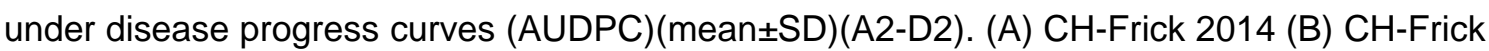
2015, (C) I-San Michele 2015, (D) GR-Veria 2015. 'Control' non-treated, 'Cu' $0.3 \mathrm{~g} \mathrm{Cu}^{2+} \mathrm{L}^{-1}$, 'Strategy' acidified clay minerals plus sulphur, change to $\mathrm{Cu}^{2+}$ around bloom, 'Co-Cu-Co' 3 $\mathrm{Cu}^{2+}$ treatments around bloom, otherwise untreated. Different lower case letters indicate significant differences between treatments at individual dates (A1-D1) or between treatments (A2-D2) (ANOVA on arcsin- (severity) or log-(AUDPC) tansformed data ( $\alpha=5 \%)$ followed by a post-hoc Tukey-B test) 